\title{
Diabetes melitus meningkatkan kejadian pruritus vulva pada perempuan lanjut usia
}

\author{
Sri Mielda Nurliani Dewi ${ }^{1}$ Adi Hidayat ${ }^{2}$
}

\begin{abstract}
ABSTRAK
\section{LATAR BELAKANG}

Pada lanjut usia (lansia) terjadi proses penuaan serta penurunan kapasitas fisik seseorang akibatnya menjadi kurang produktif, rentan, dan banyak bergantung pada orang lain. Perempuan lansia biasanya sudah mengalami menopause dan penurunan fisik berhubungan dengan perubahan hormonal. Menurunnya kadar estrogen pada menopause mengakibatkan perubahan pada vulva dan vagina yang memudahkan perempuan lansia mengalami infeksi bakterial. Women's health initiative menunjukkan prevalensi perempuan lansia yang menderita pruritus vulva mencapai $27 \%$. Pruritus vulva seringkali dikaitkan dengan diabetes melitus walaupun hal ini masih kontroversial. Tujuan penelitian ini untuk menentukan hubungan antara diabetes melitus dan pruritus vulva pada perempuan lansia.
\end{abstract}

\section{METODE}

Sebuah studi analisis observasional dengan pendekatan desain penelitian potong silang mengikutsertakan 197 perempuan lansia. Penelitian dilaksanakan bulan September-November 2017. Sebuah kuesioner digunakan untuk mengumpulkan data mengenai usia, pendidikan, status pernikahan dan pekerjaan. Kadar gula darah sewaktu diukur menggunakan glukometer Unesco dan kuesioner digunakan untuk mengukur pruritus vulva. Analisis data dengan menggunakan uji Chisquare $u$ ntuk menganalisis data dengan tingkat kemaknaan 0,05 .

\section{HASIL}

Sebanyak 91,9\% subjek berusia antara 60-69 tahun, 62,4\% mengalami diabetes melitus (kadar gula darah sewaktu $>200 \mathrm{mg} / \mathrm{dL}$ ) dan 71,9\% mengalami pruritus vulva. Hasil uji Chi-square menunjukkan adanya hubungan yang bermakna antara diabetes melitus dan pruritus vulva $(\mathrm{p}=0,000)$.

\section{KESIMPULAN}

Penelitian ini menunjukkan diabetes melitus meningkatkan kejadian pruritus vulvae pada perempuan lansia, sebaiknya dianjurkan untuk melakukan pemeriksaan kadar gula darah sewaktu secara berkala untuk mencegah terjadinya pruritus vulvae.

Kata kunci : kadar gula darah sewaktu, pruritus vulvae, lansia perempuan

\author{
${ }^{1}$ Program Studi Kedokteran, \\ Fakultas Kedokteran, \\ Universitas Trisakti \\ ${ }^{2}$ Departemen Ilmu Kesehatan \\ Masyarakat, \\ Fakultas Kedokteran, \\ Universitas Trisakti \\ Korespondensi: \\ Adi Hidayat \\ Departemen Ilmu Kesehatan \\ Masyarakat, \\ Fakultas Kedokteran, \\ Universitas Trisakti \\ Email : hidayat.adi@trisakti.ac.id
}

J Biomed Kes 2018;1(1):109-116 DOI: 10.18051/JBiomedKes.2018. v1.109-116

pISSN: 2621-539X / eISSN: 2621-5470

Artikel akses terbuka (open access) ini didistribusikan di bawah lisensi Creative Commons Attribution 4.0 International (CC-BY 4.0) 


\section{ABSTRACT}

\section{Diabetes melitus increase pruritus vulvae in elderly women}

\section{BACKGROUND}

In the elderly, the aging process will decrease in physical capacity. In this phase of life, a woman has already gone through menopause and its associated emotional, physical, and hormonal changes. These changes are due to gradual loss of estrogen that comes with menopause which results in dramatic changes in the appearance of vulva and makes the person prone to bacterial infections. Women's health initiative showed that the prevalence of pruritus vulvae in elderly women was $27 \%$. Pruritus vulvae is often reported to be associated with diabetes mellitus although this remains controversial. The purpose of this study was to determine the relationship between diabetes mellitus and pruritus vulvae in elderly women.

\section{METHODS}

An observational study with cross sectional design was conducted involving 197 elderly women. The study was conducted in September-November 2017. A questionnaire was used to collect data on age, educational status, marriage status, and occupational. The random blood sugar levels was measured using glucometer Unesco and pruritus vulvae with questionnaires. Chi-square test was to use to analyse the data and the level of significance was 0.05 .

\section{RESULT}

A total of $91.9 \%$ subjects were $60-69$ years of age, $62.4 \%$ had diabetes mellitus (random blood sugar levels $>$ $200 \mathrm{mg} / \mathrm{dL}$ ) and $71.9 \%$ had pruritus vulvae. There was a significant relationship between diabetes mellitus and pruritus vulvae $(\mathrm{p}=0.000)$.

\section{CONCLUSION}

This study demonstrated that diabetes mellitus increased prutitus vulvae in elderly women. Routine random blood glucose levels examination is recommended in elderly women to prevent pruritus vulvae.

Keywords : blood sugar levels, pruritus vulvae, elderly women

\section{PENDAHULUAN}

\section{Menurut World Health Organization} (WHO) lanjut usia (Lansia) adalah seseorang yang telah mencapai usia 60 tahun atau lebih. Populasi lansia menghadapi beragam masalah kesehatan dan memerlukan layanan kesehatan. (1) Lanjut usia merupakan masa dimana seseorang sudah tidak ada lagi mengalami peningkatan kualitas fisik, melainkan yang dimulai dengan adanya beberapa perubahan fungsi fisik dalam hidup. ${ }^{(2)}$ Berdasarkan Pusat Data dan Informasi dari Kementerian Kesehatan RI, proporsi penduduk lansia di Indonesia pada tahun 2012 sebesar 7,59\%. Nampak adanya peningkatan persentase kelompok lansia sejak tahun 2013 sebesar 8,9\% di Indonesia hingga tahun 2050 sebesar $21,4 \%$, dan 2100 sebesar $41 \%$. $^{(3)}$ Proses penuaan merupakan tantangan yang harus ditanggulangi karena diartikan dengan proses penurunan kapasitas fisik seseorang. Akibatnya lansia menjadi kurang produktif, rentan terhadap penyakit dan banyak bergantung pada orang lain, maka tidak hanya kapasitas fisik seorang lansia yang menurun tetapi kualitas hidup seorang lansia juga ikut serta menurun.(4) Masalah kesehatan yang paling umum pada perempuan kelompok lansia adalah hipertensi, osteoartritis, diabetes mellitus (DM), atau asma bronkial. Dan yang lainnya termasuk katarak, anemia, dan masalah kulit. ${ }^{(5)}$ Kulit pada lanjut usia yang kering dan retak (chapped skin) mudah menjadi pruritus. Lokasi tersering ialah daerah genital eksterna, perineal dan perianal. ${ }^{(6)}$

Pruritus vulvae adalah gangguan yang ditandai dengan sensasi gatal yang parah di alat kelamin eksternal perempuan. Gatal pada organ genitalia eksterna perempuan merupakan sebuah gejala, dan bukan sebuah diagnosis patologis. (7) Pruritus vulvae biasanya terjadi pada malam hari. Ketika sedang tidur memungkinkan seseorang menggaruk tanpa menyadarinya yang menyebabkan memar sampai berdarah. Pada tahap selanjutnya pruritus vulvae mempengaruhi kehidupan sosial seorang perempuan. $^{(8)}$

Prevalensi kejadian pruritus vulvae secara umum $1-5 \%$ pada perempuan dengan segala usia. ${ }^{(9)}$ Studi pada perempuan lansia menunjukkan prevalensi perempuan lansia yang menderita pruritus vulvae besarnya 
27\%. ${ }^{(8)}$ Penyebab pruritus vulvae pada lansia adalah atrophic vaginitis, lichen sclerosis, perempuan dengan DM, candidiasis, dan infeksi dermatopik lainnya. ${ }^{(10)}$

Diabetes melitus merupakan suatu kelompok penyakit metabolik dengan karakteristik peningkatan kadar gula darah (hiperglikemia) yang terjadi karena kelainan sekresi insulin, kerja insulin atau keduaduanya. ${ }^{(11)}$ Diabetes melitus selalu berhubungan dengan kadar gula darah, baik itu kadar gula darah sewaktu, puasa, post prandial, maupun HbA1C. ${ }^{(12)}$ Menurut WHO yang memprediksi adanya kenaikan jumlah penderita DM di Indonesia dari 8,4 juta jiwa pada tahun 2000 , menjadi sekitar 21,3 juta jiwa pada tahun 2030. Sedangkan International Diabetes Federation (IDF) memprediksi kenaikan jumlah penderita DM dari tujuh juta pada tahun 2009 menjadi 12 juta tahun pada 2030. Keduanya menunjukkan adanya peningkatan jumlah penderita DM sebanyak 2-3 kali lipat pada tahun 2030.(13) Riset Kesehatan Dasar (Riskesdas) melaporkan pada tahun 2013 terdapat 2,4\% kejadian DM di Indonesia. Berdasar hasil riset kesehatan dasar yang dilakukan oleh Kementerian Kesehatan RI yang memiliki prevalensi DM tertinggi pada kelompok umur 55-64 tahun sebesar 5,5\%, 4,8\% pada kelompok umur 65-74 tahun, dan 3,5\% pada kelompok umur $>75$ tahun. Prevalensi DM menurut jenis kelamin didapatkan perempuan $>$ laki-laki. (5) Prevalensi DM tertinggi didapatkan pada penduduk berusia 60 tahun atau lebih dengan insidens tertinggi juga didapatkan pada kelompok usia tersebut. $^{(5)}$

Nair $\mathrm{dkk}^{(7)}$ menunjukkan bahwa lansia yang DM sering mengalami prutitus. Hasilyang sama ditunjukkan pada penelitan Rodriguez $\mathrm{dkk}^{(8)}$ bahwa terdapat hubungan antara DM dan pruritus. Penelitian dari Weisshaar dkk ${ }^{(9)}$ menunjukkan hasil yang berbeda, bahwa tidak terdapat hubungan antara DM dan pruritus.

Hasil-hasil penelitian yang masih belum konsisten memerlukan penelitian lebih lanjut. Penelitian ini bertujuan untuk menentukan hubungan antara DM dan pruritus vulvae pada perempuan lansia.

\section{METODE}

\section{Rancangan penelitian}

Penelitian ini menggunakan metode observasional analitik dengan desain penelitian cross-sectional yang dilakukan di Kelurahan Pejuang Kecamatan Medan Satria Kota Bekasi pada bulan SeptemberNovember 2017.

\section{Subjek penelitian}

Sebanyak 197 perempuan lansia merupakan subjek penelitian ini. Kriteria inklusi adalah perempuan berusia 60 tahun keatas, mampu berkomunikasi, mandiri yang tidak memerlukan bantuan orang lain dan bersedia mengisi inform consent. Perempuan lansia yang mengalami kelainan kulit pada vulvanya yang didiagnosis oleh dokter dikeluarkan dari penelitian ini. Penentuan besar sampel dilakukan menggunakan rumus;

$$
\begin{aligned}
\mathrm{n}= & \mathrm{Z} \alpha 2 \times \mathrm{p} \times \mathrm{q} / \mathrm{d} 2 \\
\mathrm{n}= & \text { besar sampel optimal yang dibutuhkan } \\
\mathrm{z} \alpha= & \text { pada tingkat kemaknaan } 95 \% \text { besarnya } \\
& 1,96 \\
\mathrm{p}= & \text { prevalensi perempuan lansia yang } \\
& \text { mengalami pruritus vulvae sebesar } 27 \% \\
\mathrm{q}= & \text { prevalensi perempuan lansia yang tidak } \\
& \text { mengalami pruritus vulvae sebesar } 83 \% \\
\mathrm{~d}= & \text { akurasi dari ketepatan pengukuran } \\
& \text { besarnya } 0,05
\end{aligned}
$$

Pada populasi yan gfinit harus dikoreksi :

$$
\begin{aligned}
& \mathrm{n}=\mathrm{n} 0 /(1+\mathrm{n} 0 / \mathrm{N}) \\
& \mathrm{n}=\text { besar sampel yang dibutuhkan untuk } \\
& \text { populasi yang finit } \\
& \mathrm{n} 0=\text { besar sampel dari populasi yang infinit } \\
& \mathrm{N}=\text { jumlah lansia perempuan sebesar } 393 .
\end{aligned}
$$

Besar sampel yang diperlukan setelah ditambah drop out sebesar 15\% adalah 197 . Pemilihan subjek penelitian dilakukan menggunakan cluster dan simple random sampling.

\section{Pengumpulan data}

Pengumpulan data dilakukan dengan cara wawancara menggunakan kuesioner untuk mengetahui karakterisktik sosiodemografi (usia, staus pernikahan 
dan pekerjaan), dan pruritus vulvae diukur menggunakan kuesioner yang telah digunakan pada penelitian Elman dkk. ${ }^{(10)}$ Pruritus vulvae pada penelitian ini dibagi dalam 3 kelompok : i) tidak (skor 0) ;ii)ringan (skor 9-20); dan iii) berat (skor $>20$ ).

\section{Laboratorium analisis}

Sampel darah kapiler dari jari tengah digunakan untuk mengukuar kadar gula darah sewaktu dengan menggunakan alat glukometer Unesco yang telah divalidasi. Kadar gula darah sewaktu dinyatakan dalam $\mathrm{mg} / \mathrm{dL}$. Kadar gula darah sewaktu dibagi dalam 3 kelompok :i). normal $(<100 \mathrm{mg} /$ dL);ii) pra-diabetik (100-125mg/dL);dan iii) diabetic (DM) (>200mg/dL).

\section{Analisis statistik}

Secara deskriptif data disajikan dalam bentuk persen. Uji chi-square digunakan untuk menguji hubungan antara DM dan pruritus vulvae. Tingkat kemaknaan yang digunakan besarnya 0,05 .

\section{Kaji etik}

Protokol penelitian ini telah memperoleh kelayakan etik dari Komisi Etik Riset Fakultas Kedokteran Universitas Trisakti dengan No.148/KER-FK/VII/2017.

\section{HASIL}

\section{Karakteristik sosiodemografi, DM dan pruritus vulva}

Sebagian besar 181 (91,9\%) subjek berusia antara 60 - 69 tahun, berpendidikan tidak sekolah 80 (40,6\%), menikah 196 $(99,5 \%)$ dan 97 ( $49,2 \%$ bekerja sebagai ibu rumah tangga. Subjek yang mengalami DM besarnya $123(62,4 \%)$ dan $68(34,5 \%$ mengalami pruritus vulvae yang berat (Tabel $1)$.

Hasil uji chi-square menunjukkan pada lansia perempuan yang mengalami DM (kadar gula darah sewaktu $>200 \mathrm{mg} / \mathrm{dL}$ ) terdapat 68 (55,3\%0 yang mengalami pruritus vulvae yang berat, lebih besar secara bermakna dibandingkan lansia perempuan yang normal sebesar $0(0,0 \%)(p=0,000)($ Tabel 2). Kadar gula darah sewaktu yang tinggi meningkatkan pruritus vulvae pada lansia perempuan.

Tabel 1. Distribusi karakteristik sosiodemografi, kadar gula darah sewaktu dan pruritus vulvae responden $(\mathrm{n}=197)$

\begin{tabular}{lc}
\hline \multicolumn{1}{c}{ Variabel } & n (\%) \\
\hline Umur (tahun) & $181(91,9)$ \\
$\quad 60-69$ & $16(8,1)$ \\
$\quad>69$ & $196(99,5)$ \\
Status pernikahan & $1(0,5)$ \\
Menikah & \\
Tidak menikah & $80(40,6)$ \\
Pendidikan & $54(27,4)$ \\
Tidak sekolah & $25(12,7)$ \\
SD & $31(15,7)$ \\
SMP & $7(3,6)$ \\
SMA & \\
Sarjana & $81(41,1)$ \\
Pekerjaan & $97(49,2)$ \\
Tidak berkerja & $19(9,7)$ \\
Ibu rumah tangga & \\
Pedagang & $35(17,8)$ \\
Diabetes mellitus & $39(19,8)$ \\
Tidak & $123(62,4)$ \\
Pra-diabetik & \\
Diabetik & $75(38,1)$ \\
Pruritus vulvae & $54(27,4)$ \\
Tidak & $68(34,5)$ \\
Ringan & \\
Berat & \\
\hline
\end{tabular}

\section{PEMBAHASAN}

Penelitian kami menujukkan terdapat hubungan yang bermakna antara DM dengan pruritus vulvae pada lansia perempuan. Hasil yang tidak berbeda didapatkan pada penelitian yang dilakukan oleh Bakinejad dkk(11) pruritus vulvae pada wanita DM secara signifikan lebih tinggi dibandingkan dengan tidak DM. Penelitian oleh Weisshaar dkk(12) juga mendapatkan hasil yang tidak berbeda yaitu pruritus vulvae secara signifikan lebih sering terjadi pada wanita DM $(18,4 \%)$ dibandingkan dengan wanita yang tidak mengalami $(5,6 \%)$. Hasil penelitian Timshina $\mathrm{dkk}^{(13)}$ dari 34 kasus $(15,2 \%)$ pruritus vulvae dan enam $(7,4 \%)$ sebagai kontrol terdapat hasil signifikan secara statistik meningkat insidensi pruritus pada penderita Ddibandingkan bukan penderita DM. Sedangkan hasil penelitian yang dilakukan Weisshaar $\mathrm{dkk}^{(9)}$ dari hasil penelitian ini tidak terdapat hubungan antara DM dengan pruritus. 
Tabel 2. Hubungan kadar gula darah sewaktu, karakteristik sosiodemografi dan pruritus vulvae pada lansia perempuan

\begin{tabular}{|c|c|c|c|c|}
\hline \multirow[t]{2}{*}{ Variabel } & \multicolumn{3}{|c|}{ Pruritus vulvae } & \multirow[t]{2}{*}{ nilai p } \\
\hline & Tidak $(n=75)$ & Ringan $(n=54)$ & Berat $(n=68)$ & \\
\hline \multicolumn{5}{|l|}{ Diabetes melitus } \\
\hline Normal & $35(100 \%)$ & $0 \quad(0,0 \%)$ & $0 \quad(0,0 \%)$ & \multirow{3}{*}{$0,000^{*}$} \\
\hline Pra-diabetik & $39(100 \%)$ & $0 \quad(0,0 \%)$ & $0 \quad(0,0 \%)$ & \\
\hline Diabetik & $1 \quad(0,8 \%)$ & $54(43,9 \%)$ & $68(55,3 \%)$ & \\
\hline \multicolumn{5}{|l|}{ Umur (tahun) } \\
\hline $60-69$ & $61(33,7 \%)$ & $52(28,7 \%)$ & $68(37,6 \%)$ & \multirow[t]{2}{*}{$0,000^{*}$} \\
\hline$>69$ & $14(87,5 \%)$ & $2(12,5 \%)$ & $0 \quad(0,0 \%)$ & \\
\hline \multicolumn{5}{|l|}{ Pendidikan } \\
\hline Tidak sekolah & $18(22,5 \%)$ & $15(18,8 \%)$ & $47(58,8 \%)$ & \multirow{3}{*}{$0,000 *$} \\
\hline SD - SMP & $35(44,3 \%)$ & $24(30,4 \%)$ & $20(25,3 \%)$ & \\
\hline SMA - Sarjana & $22(57,9 \%)$ & $15(39,5 \%)$ & $1 \quad(2,6 \%)$ & \\
\hline \multicolumn{5}{|l|}{ Pekerjaan } \\
\hline Tidak bekerja & $25(30,9 \%)$ & $18(22,2 \%)$ & $38(46,9 \%)$ & \multirow{3}{*}{$0,008 *$} \\
\hline Ibu rumah tangga & $39(40,2 \%)$ & $29(29,9 \%)$ & $29(29,9 \%)$ & \\
\hline Pedagang & $11(57,9 \%)$ & $7 \quad(36,8 \%)$ & $1 \quad(5,3 \%)$ & \\
\hline
\end{tabular}

Penelitian kami menunjukkan ada hubungan bermakna antara umur dan pruritus vulvae yang sesuai dengan penelitian Stander $\mathrm{dkk}^{(14)}$, Wei $\mathrm{dkk}^{(15)}$, dan Pereira $\mathrm{dkk}^{(16)}$ yang melaporkan terdapat hubungan positif antara pruritus dan usia.

Berdasarkan hasil penelitian kami ini terdapat hubungan yang bermakna antara pendidikan dengan pruritus vulvae. Semakin tinggi pendidikan seseorang maka semakin banyak mengerti dan mengetahui informasi kesehatan, begitupun sebaliknya semakin rendah pendidikan maka semakin kurang mengerti dan mengetahui informasi tentang kesehatan. ${ }^{(17-19)}$

Pendidikan berperan dalam mempengaruhi seseorang untuk berperilaku sehat dan berperan dalam perubahan perilaku kesehatan. ${ }^{(20)}$ Akan tetapi hasil ini tidak sejalan dengan penelitian yang menujukkan bahwa tingkat pendidikan tidak berhubungan dengan pruritus vulvae.(21-22)

Dalam pelaksanaan penelitian ini, didapatkan keterbatasan dalam melakukan penelitian, pertama alat bantu diagnostik hanya menggunakan kuesioner, sebaiknya menggunakan pemeriksaan diagnostik pruritus vulvae seperti pemeriksaan fisik. Kedua, rancangan penelitian yang digunakan adalah potong silang yang tidak dapat menjelaskan adanya hubungan sebab akibat. Penelitian lebih lanjut diperlukan dengan rancangan yang lebih baik misalkan kohort sehingga dapat menentukan hubungan sebab akibat.

\section{KESIMPULAN}

Penelitian ini berhasil membuktikan DM meningkatkan kejadian pruritus vulva pada perempuan lansia. Perempuan lansia perlu melakukan pemeriksaan kadar gula darah sewaktu untuk mencegah terjadinya pruritus vulva.

\section{UCAPAN TERIMA KASIH}

Peneliti mengucapkan terima kasih kepada semua perempuan lansia di Kelurahan Pejuang Kecamatan Medan Satria Kota Bekasi yang telah bersedia ikut serta pada penelitian ini. Kepada semua pihak yang telah membantu terlaksanaya penelitian ini para peneliti mengucapkan terima kasih.

\section{KONFLIK KEPENTINGAN}

Para peneliti tidak memiliki kepentingan pada penelitian ini.

\section{KONTRIBUSI PENULIS}

SMND dan AH berkontribusi pada penulisan makalah dan analisixs data. SMND berkontribusi pada pengumpulan data. AH berkontribusi pada perbaikan makalah. Semua 
penulis telah membaca dan memberikan perestujuan terhadap makalah yang final.

\section{DAFTAR PUSTAKA}

1. World Health Organization. Ageing and Life Course. Geneva : World Health Organization;2017.

2. Basuki W. Faktor - faktor penyebab kesepian terhadap tingkat depresi pada lansia penghuni panti sosial tresna werdha nirwana puri kota samarinda. eJournal Psikologi 2015;4:713-30.

3. Pusat Data dan Informasi Kementerian Kesehatan RI. Situasi lanjut usia di Indonesia. Jakarta : Pusat Data dan Informasi Kementerian Kesehatan RI;2016

4. Perkumpulan Endokrinologi Indonesia (PERKENI). Konsensus pengendalian dan pencegahan diabetes mellitus tipe $2 \mathrm{di}$ Indonesia. Jakarta: PB Perkeni;2011.

5. Badan Penelitian dan Pengembangan Kementerian Kesehatan Republik Indonesia. Riset Kesehatan Dasar (RISKESDAS). Jakarta : Badan Penelitian dan Pengembangan Kesehatan Kementrian Kesehatan RI; 2013.

6. Khairani R. Prevalensi diabetes mellitus dan hubungannya dengan kualitas hidup lanjut usia di masyarakat. Univ Med 2007;26:18-26.

7. Nair PA, Vora R. Association of systemic diseases with cutaneous dermatosis in elderly population: preliminary observation at a rural tertiary care centre. J Family Med Prim Care 2015;4:74-8. doi: 10.4103/2249-4863.152259.

8. Rodriquez VR, Mollanazar NK, Muro GJ, et al. Itch prevalence and characteristics in a Hispanic geriatric population: a comprehensive study using a standardized itch questionnaire. Acta Derm Venereol 2015;95:417-21. doi: 10.2340/000155551968.

9. Weisshaar E, Kucenic MJ, Fleischer AB. Pruritus. Acta Derm Venereol 2003;213 Suppl:5-32.

10. Elman S, Hynan LS , Gabriel V, Mayo
MJ. The 5-D itch scale: a new measure of pruritus. Br J Dermatol 2010;162: 587-93. doi:10.1111/j.1365-2133.2009.09586.x.

11. Bakinejad P, Walton S. Diabetes and pruritus. Br J Diabetes 2016;16:154-6. http://dx.doi.org/10.15277/bjd.2016.095

12. Weisshaar E, Dalgard F. Epidemiology of itch: adding to the burden of skin morbidity. J Compilation Acta DermVenereol 2009;89:339-50.

13. Timshina DK, Thappa DM, Agrawal A,. A clinical study of dermatoses in diabetes to establish its markers. Indian J Derm 2012; 57: 20-5. DOI: 10.4103/0019-5154.92671.

14. Stander S, Schafer I, Phan NQ, et al. Prevalence of chronic pruritus in Germany: results of a cross sectional study in a sample working population of 11,730 . Dermatology 2010;221:229-35.

15. Wey SJ,Chen DJ. Common cutaneous disorders in the elderly. JClin Gerontol Geriatr 2010;1:36-41. doi:10.1016/j. jcgg.2010.10.010.

16. Pereira M, Stander S. Therapy for pruritus in the elderly: a review of treatment development. J Expert Opinion Pharmacother 2018; 19;443-50. https:// doi.org/10.1080/14656566.2018.1444752

17. Rana AKM, Wahlin A, Lundborg CS, Kabir ZH. Impact of health education on health-related quality of life among elderly persons: results from a community-based intervention study in rural Bangladesh. Health Promot Int 2009;24:36-45. doi:10.1093/heapro/dan042.

18. Kye B, Arenas E, Teruel G, Rubalcava. Education, elderly health, and differential population aging in South Korea: A demographic approach. Demographic Res 2014;30:753-94. DOI: 10.4054/ DemRes.2014.30.26.

19. De Guzman PB, Merwin EI, Bourguignon C. Population density,distance to public transportation, and health of women in low-incomeneighborhoods. Public Health Nursing 2013; 30:488-490.

20. Johnston DW, Lordan G,Shields MA, Suziedely A. Education and 
health knowledge: Evidence from UK compulsory schooling reform. Social Sci Med 2015;92-100. https://doi. org/10.1016/j.socscimed.2014.10.026.

21. Berger TG, Shive M, Harper GM. Pruritus in the Older Patient : A Clinical Review. JAMA 2013;310:2443-50. doi:10.1001/ jama.2013.282023.

22. Clerc CJ, Misery L. A Literature Review of Senile Pruritus: From Diagnosis to Treatment. Acta Derm Venereol 2017; 97 : 433-40. doi: 10.2340/00015555-2574. 